\title{
EFFECTS OF SOCIAL REFORMS OF SHAYKH AHMAD SIRHINDI (1564-1624) ON MUSLIM SOCIETY IN THE SUB CONTINENT
}

\author{
Adnan Malik \\ Muhammad Zubair ${ }^{* *}$ \\ Uzma Perveen ${ }^{* * *}$
}

\begin{abstract}
s
History in this age needs to record and analyze the events in the light of modern concept of contemporary world. When the historians narrate the brutal condition of Indo-Pak history, they never forget the work and services of Shaykh Ahmad Sirhindi to transform the society according to the current values. For his services, he is hailed as Mujaddid Alf-I-Thani (reformer of the second millennium). The Muslim society had degenerated when Mujaddid Alf-I-Thani appeared on the horizon. A number of Hindu customs and practices had become the part of their creed. The commandments of Shariat and Sunnah were being floated. Moreover, the Mughal emperor Akbar had adopted controversial policies detrimental to the very existence of Muslim society. Mujaddid-Alf-Thani made strenuous and constant efforts to turn the tide. When Mujadded-Alf-Thani started his social reform movement, he found that the Muslim society was embracing un-Islamic practices such as widespread belief in Karamat (miracles of saint) had developed under the influence of Hindu thinking. Moreover, the Islamic teachings had been vitiated by adopting customs and practices of other religions such as inter marriages between Hindus and Muslims and ban on cow slaughter etc. Shaykh Ahmad Sirhindi never entered into any political conflict directly. He endeavored to restore pure doctrine to Islamic thought and to compel the Muslims to follow Shariat and Sunnah in letter and spirit. He was a social reformer, great Alim, Sufi and Mujaddid. He initiated a process of social change, inspired by Islamic Ideal, in an age, which was becoming secular. This research paper is an attempt to mention the role of Shaykh Ahmad Sirhindi for saving the society from un-Islamic values and customs in the sub-continent and its impact on society. By utilizing the historical method, this paper aims at analyzing the effect of social reforms of Shaykh Ahmed Sirhindi (1564-1624) on Muslim society.
\end{abstract}

Keywords: Shaykh Ahmad Sirhindi, subcontinent, Shariah, Sunnah, social reforms

\section{Introduction}

Social reforms, which described by the Holy Quran ${ }^{1}$ play a vital role in developing a society. These reforms include belief, worship, ethics and laws pertaining social,

\footnotetext{
* Adnan Malik, Ph.D. Student, Department of Islamic History, University of Karachi

${ }^{* *}$ Muhammad Zubair, Ph.D. Associate Professor and Chairman, Department of Islamic History University of Karachi

${ }^{* * * *}$ Uzman Perveen, Ph.D. Assistant Professor, Department of Islamic History University of Karachi
} 
economic and civic matters. Similar teachings were also given in $\mathrm{Tora}^{2}$ to Bani Israel and they are known among Jews and Christians as the Ten Commandments. Allaha's universal message is explained in the Holy Quran:

...say Come I will tell you what your Lord has really forbidden you. Do not ascribe anything as partner to Him; be good to your parents; do not kill your children in fear of poverty' - We will provide for you and for them - 'stay well away from committing obscenities, whether openly or in secret; do not take the life Allah has made sacred, except by right. This is what $\mathrm{He}$ commands you to do; perhaps you will use your reason. Stay well away from the property of orphans, except in the way that is best, until they come of age; give full measure and weight, according to justice' - We do not burden any soul with more than it can bear - 'when you speak, be just, even if it concerns a relative; keep any promises you make in Allah s name.' This is what $\mathrm{He}$ commands you to do, so that you may take heed. This is my path leading straight, so follow it, and do not follow other ways they will lead you away from it- 'This is what He commands you to do, so that you may refrain from wrongdoing. ${ }^{3}$

The efforts of Holy Prophets could be considered those universal social reforms which aimed to bring all encompassing changes in the society of their times. After the Holy prophet (S.A.W), this tradition of Islamic reformists continued throughout the history. Imam Malik (R.A) made strong movement raising voice against forcing baiat in Abbasid period. Imam Abu Hanifa (R.A) did not accept the any right of in ruler ship. Imam Ahmad bin Hambal (R.A) also raised the banner of resistance by refuting the claim of Mutazilites. Imam Ghazali, Hasan Basri, Ibn Taimiyya and Ibn-i-Qayyam were all the personalities who devoted their lives to establish and revive the social values under the flag of Islam. During the Mughal period in South Asia, the Muslim society was involved a number of Hindu Customs and practices that were opposite of the commandments of Quran and Sunnah. The Muslims were inclined to learn Hindu teachings ${ }^{4}$. In order to find a middle ground among Hindu, Jain, Parsi and Islam, Mughal Emperor Akbar proclaimed his Din-i-Illahi. As a result, Islamic teachings had been vitiated by adopting customs and practices of other religions. Besides, Muslim society came up Hindu culture and civilization ${ }^{5}$. In this condition of the sub-continent, there was a great Alim named shaykh Ahmad sirhindi (1564/971- 1624/1034) ${ }^{6}$ popularly known Mujaddid Alf Thani ${ }^{7}$. He emphasized the reformation of the individual as well as society. He saved the Muslim society from dogmatism and secular beliefs of unorthodox mystics through his social reforms that are purely based on Sunnah. The basic objective was the implementation of Islamic Laws and Shariat.

${ }^{1}$ The Holy Quran, Surah Al Anum, Ayat No `51.152.

${ }^{2}$ 2.Tora, Exodus, 20.

${ }^{3}$ Al Qur'an, Al-An'am 6:151-153

${ }^{4}$ Khaliq Ahmed, State and Culture in Medieval India, 451.

${ }^{5}$ Abdul Qader, Muntaakahbut Tawarikh,261.

${ }^{6}$ Sharif, A History of Mslim Philosophy,873-83.

${ }^{7}$ Renewal of the second millennium 


\section{Objectives of the study}

- To investigate the role of Shaykh Ahmad Sirhindi for saving the society from un-Islamic values and customs in the sub-continent.

- To shed light on the condition of the sub-continent during Akbar's era

- To probe the impacts of social reforms of Shaykh Ahamd Sirhindi on Muslim society in the sub con-continent.

\section{Methodology}

Qualitative research approach has been adopted. Hatch (2002) defined that qualitative method of research assigns significance to human beings. Moreover, this approach of research is suitable as it also takes into account the cultural aspect of a society. Primary and secondary sources were used to collect the data and then analyze it.

\section{Shaykh Ahamd Sirhindi at a Glance}

He was born on $14^{\text {th }}$ Shawwal, 971 A.H 26 May, 1564 A.D. ${ }^{8}$ at Sirhind ${ }^{9}$. He received his early education from his father shaykh Abdul Ahad and other renowned scholars of Sirhind. During the studying Hadith and Tafseer, the Emperor Akbar's close courtiers Abdul Fazal and Fazi heard brilliancy of Shakh Ahmad Sirhindhi. Both of them tried to make a good relation with Shaykh Ahmed Sirhindi. However, when Shaykh Ahmad Sirhindhi talked on some educational problems with Abul Fazal and Fazi in his personal meeting, this relationship could not continue for a long time. Shaykh Ahmad Sirhindi completed contemporary Islamic education at the age of seventeen and became a mureed (follower) of a great Naqshbandi Alim Khawaja Muhammad Baqi Billah ${ }^{10}$. Due to the having great abilities, Shaykh Ahmad Sirhindi had got Naqshbandi status in just two and a half month ${ }^{11}$. After khawaja Baqi Billah's death, (1603-4/1012 A.H) Shaykh Ahmad Sirhindi held the khwaja's School of thought. The current situation of the Subcontinent showed that only the Mujaddi movement and his school of thought could achieve a great success in the development and existence of Islamic ideology in the society. In this regard, Shaykh Ahmad Sirhindi played a vital role.

\section{Condition of the Sub-Continent During Akbar's Era}

The Mughal Emperor Akbar (1542/1605) died when Shaykhd Ahmad Sirhindi was only 43 years old. We have a brief look of the religious thinking of king Akbar's era and its impact on society. In the beginning, Akbar was a complete religious man. In Darbar-iAkbari Muhammad Hussain Azad has explained following views about his period which are also confirmed from authoritative history books.

\footnotetext{
${ }^{8}$ Main, Ulama Hind Ka Shandar Madhi, 04.

${ }^{9}$ Shirind Sharif is a famous city in India.

${ }^{10}$ Hashmi, Zubadtu. Muqamat, p.137.

${ }^{11}$ Ibid, p. 195
} 
For 18 to 20 years, like other straight-forward sincere and devoted Muslim he used to listen to the commands of Shari'at with respect and used to obey them with sincerity. He used to offer prayers with Jama'a, used to say Azan, used to broom the mosque himself, used to pay very much respect to Ulema and Fudala (the learned and the scholars), used to visit their residences, used to put orderly the shoes of some of them. State suits used to be decided according to the Fatwa of the shari'at. At different places he had appointed Qadi and Mufti. He used to treat the Fuqara and Mushaikh (saints and hermits) with complete faith and from the blessing of their presence used to obtain beneficence for his state affairs....

Despite of performing all these activities, due to his (un-Islamic) peace loving nature and receiving political benefit, he had also married Hindu ladies. As a result, a number of Hindu customs and practices had become the part of state. Moreover, Akbar also waived Jaziya (an Islamic tax recovered from Non-Muslims subject to safeguard their lives and property and to give all facilities as a citizen) which was re-imposed by Aurangzaib in 1697. Ibadat-Khana(place of worship was built where every Friday night gathering used to be held in which Ulema and Mashaikhs of every school of thought used to participate in which the king Akbar used to give awards and appreciations. These rewards and appreciations became the root cause of malice and enmity among the ulema. As per Mulla Abdul Qadir Badayni wrote his book "They used to start war of words and openly used to call each other Kafir and Heretic"13. Besides, the proclamation of Din-i-Illahi by Emperor Akbar is considered to be one of the biggest controversies of Islamic history in the sub-continent. In order to find a middle ground between Hinduism and Islam, Akbar proclaimed his Din-i-Illahi or divine faith in 1581. Scholar of London University Peter Hardy has expressed the following views about it:

Din-i-Illahi ideologically was "Mutasufana" (Immature mystical). The Zorastrain beliefs were also included in it but this religion was purely Unitarian. $^{14}$

However, the views expressed by the American historian Powell price are more realistic. He writes:

In 1582 CE Din-i-Illahi was founded. This new religion was an abstract and unequivocal shape of the doctrine of Tuihid-i-Wujudi in which beliefs of different religions are included. It is a mixture of Zorastrain, Jaiani, Hindu, Budhhist religion and Islam theory of Tauhid has been included only for the name shake. ${ }^{15}$

\section{Effects of Shirindi Reforms in the Subcontinent}

The influence of Shaykh Ahmad Sirhindi in the Sub-Continent has been too great. "The mission of the Mujaddid which filled a large space in the religious and political history

${ }^{12}$ Azad, Darbar-i-Akbari,44.

${ }^{13}$ Badyuni, Muntakabul Tawarikh,11.

${ }^{14}$ Debary, Source of India Tradition, 443

${ }^{15}$ Prince, A History of India, 267. 
of the Muslim community of the seventeenth century was undoubtedly success ${ }^{16}$. In his efforts Shaykh Ahmad Sirhindi was successful in neutralizing the work of Akbar and affecting a change in the mentality of his successors towards the Orthodox Islam. His teachings also had a great impact on a change in the outlook of the Muslim nobility and upper classes in general. His thought played a great role on the every section of Muslim society. Molana Abdul Kalam Azad holds only Mujaddid responsible for the reformation and revival of Islam during the Mughal period ${ }^{17}$. He considered himself more than a wali, a renovator (mujaddid) of religion who had projected to Islam at the turn of its second millennium ${ }^{18}$.

\section{Impact on Mughal Emperor Jahangir and People Around Him}

It was a great achievement of Shaykh Ahmad Sirhindi to come back the Shariat in society. He wrote a large number of letters to Government personalities emphasizing the need of true teaching of Islam. In high circle especially in high ranking officials and ministers of the government were involved a large number of evils due to their attachment with the worldly gains. Hence Shaykh Ahmad Sirhindi eradicated the evils of this class of society and through letters strongly stressed upon those to follow the direction of the Holy Prophet. The teaching and preaching of Shaykh Ahmad Sirhindi fully showed its influence on the ministers and high ranking officers and indirectly Jahangir was also influenced. To the Sarder-i-Jahan (1027/1618) who had tutored Jahangir before and enjoyed his confidence as the highest religious authority, he wrote:

Now that things have changed and the hostility of the people has subsided, it is the duty of the leaders of Islam, the Sadr-i-Islam and the 'ulma', that they work for the implementation of the Shari'ah. ${ }^{19}$

To Khan-i-Jahan (1040/1630), another official of the court, he wrote;

Since the King listens to your words and gives them weight, it would be really great if you could explain to him briefly or in detail as you like the beliefs of the Ahl al-Sunnah- wa al-jama'a. Please inform him of the doctrines of the people of the Truth (Ahl al-Haqq) and look for every opportunity to talk about Islam and the Muslim, defend the tents of Islam condemn and heresy. ${ }^{20}$

As a result, Shaykh Ahmad Sirhindi efforts had started yielding fruit. Jahangir had been influenced by Sirhindi's sincerity and devotion to Islam. The Shaykh was given an audience emperor and there he placed following demands before him:

1. prostration (Sajidah) before the emperor should be abolished; the permission to slaughter cows should be given;

2. the religious innovations should be ceased:

\footnotetext{
${ }^{16}$ Yasin, A Social History of Islamic India, 145.

${ }^{17}$ Abdul Kalam, Tazkira,264.

${ }^{18}$ Ahmed, Maktubat Imam Rabbani, Vol.I,Letter 234.

${ }^{19}$ Ibid,Vol.I, Letter, 195.

${ }^{20} \mathrm{Ibid}, \mathrm{Vol}$ II Letter 67.
} 
3. the office of the Qadi and the department of the Ihtisab should be restored; and that the mosques in need of repair should be renovated and those which had been demolished should be rebuilt ${ }^{21}$.

The emperor granted his demand and issued a royal decree accordingly ${ }^{22}$.

Thus after more than a half century's struggle for life and death, Islam came out of it's agony and the Muslims heaved a sigh of relief. ${ }^{23}$

\section{Impact on Mughal Court}

During the stay in court of Jahangir, Shaykh Ahmad Sirhindi founded the unique opportunity to preach King and the people around him. In many sessions, which he had with Jahangir, he read out the Quran to him, explained its messages, discussed the principles of faith and explained the rules of the Shari' $\mathrm{ah}^{24}$. The Emperor and the people of the Mughal court were fully influenced by the teaching of Shaykh Ahmad Sirhindi and broad-minded Emperors and people of Mughal court became an orthodox Muslims ${ }^{25}$. Hawkin tells us that he had witnessed the emperor offering the morning prayers $^{26}$. A Hindu writer says that Jahangir was conscious of his duties as a Muslim sovereign, ${ }^{27}$ and "he took greater interest in the future of Islam than his father has done and sometimes he tried to uphold this prestige ${ }^{\text {"28 }}$. On the occasion of conquest of fortness of Kangra, the idols were broken, a cow slaughtered, the khutba read, and other rites of Islam observed ${ }^{29}$ in the presence of Sirhindi ${ }^{30}$. In the same year he forbade intermarriage between Hindu men and Muslim women in Kashmir by a royal decree ${ }^{31}$. Terry, who came India between (1616-1619AD) found the mosques were full of worshippers ${ }^{32}$. Terry further tells us that the Muslims used to keep a rosary in their hands, ${ }^{33}$ and had a great respect for Quran and Hadith ${ }^{34}$. They used to keep fast during the month of Ramadhan and observe the Id'festivals ${ }^{35}$. The age limit for marriage imposed by King Akbar was abolished ${ }^{36}$. "Mohamedan confession of faith on the coins was restored by the emperor Jahangir" ${ }^{37}$. Stanly Lane Poole adds to the above statement that Jahangir also restored the hijrah chronology which his father had abandoned ${ }^{38}$. The mosques that had been abolished were rebuilt and Arabic and Islamic learning was

${ }^{21}$ Saeed, The rise and fall of Muslim,305.

${ }^{22}$ Ibid. 306

${ }^{23}$ Ehsanullah, History of Indo-pak,88-89.

${ }^{24}$ Ahmed, Maktubat Imam Rabbani, Vol III,Letter 43.

${ }^{25}$ Yasin, A Sawal History of India, 146.

${ }^{26}$ Clements, Hawakin voyager, 436.

${ }^{27}$ Roy, The State and Religion in Mughal India, 101.

${ }^{28}$ Sirvastava,The Mughal Empirer,293.

${ }^{29}$ Jehangir,Tazuk-e- Jehangere, 240.

${ }^{30}$ Sirhindi had been invited by Jehangir himself so that these Islamic rites could be performed.

${ }^{31}$ Jehangir, Tazuk-e-Jehanger, 340.

${ }^{32}$ Foster, Early Travels in India, 315.

${ }^{33}$ Ibid., 316

${ }^{34}$ Ibid., 318

${ }^{35}$ Ibid.

${ }^{36}$ Ibid., 321

${ }^{37}$ Elphinstone,Nurjahan and jehangir,78.

${ }^{38}$ Ibid. 
encouraged $^{39}$. Due to the effort of Shaykh Ahmad Sirhindi, the Mughal society began to turn into an Islamic state.

\section{Impact on Religious Teachings in Society}

Shaykh Ahmad Sirhindi thought that the main channel of mischief were the 'Ulama-i-Su (worldly minded 'Ulamas), who had taken to Fiqh (jurisprudence) as the whole of religious teachings. Sirhindi held that "every slackness and irregularity that has taken place in the matter of Shari'ah in his age, and every obstruction which has hindered the growth and expansion of Islam, is due to the wickedness of the 'Ulama-i-Su and the result of their incompetence" 40 . To turn for the better of society Shaykh Ahmad Sirhindi criticized innovation (Bid'at) in religion that was the main cause to change Islamic values. Shaykh Ahmed Sirhindi cited these verses of Holy Quran and the sayings of the Holy Prophet (P.B. U. H) against the false fact and innovation that were the main reasons to destroy the Islamic values from Society. The verses of the Holy Quran and Hadith as:

1- Today I've perfected the religion for you and have completed my favor upon you".(Quran)

2- He who invents something false which has no linkage with the religion of Islam is forbidden". (Hadith)

3- The best discourse is the discourse of Allah and the best way is the way of prophet Muhammad (PBUH) and the worst things are the inventions and every innovation in the religion is misleading"(Hadith)

4- I advise you to fear Allah Almighty and to hear you ruler and obey though he is a Negro salve. So it is a Compulsion upon you to follow my Sunnah and my Caliphs and demonstrate it strongly and avoid the innovations because every new thing is the innovation in the religion and innovation is a misleading ${ }^{41}$. (Hadith)

By the above-mentioned Hadith, (sayings of Holy Prophet) Shaykh Ahmed Sirhindi explained innovation (Bid'at) in religion the opposite of Sunnah. He gave some example to prove it. "A nation which invents innovation religion is deprived on the analogy of Sunnah" This instance of Shaykh made clear that this thing is concerned with religious matter and customary innovation does not have any connection with it ${ }^{42}$. According to the Shaykh Ahmed Sirhindi point of view, it is extremely harmful to follow the ruler who believes in any kind of innovation in religion. Shaykh Ahmad Sirhindi thought that it is a virtue to exalt Sunnah instead of innovation in religion ${ }^{43}$. He was also of the view that such newness in religion must be ruled out of the society that was reason to produce a number of different evils in the name of Islam. In our present era, there is a dire need

\footnotetext{
${ }^{39}$ Aslam, Sarmayah Umar, 128.

${ }^{40}$ Maktubat, Vol.I ,Letter 47

${ }^{41}$ Ibid., Letter, 231

${ }^{42}$ Ibid., Letter, 131

${ }^{43} \mathrm{Ibid}$, Vol. 3 letter, 105.
} 
and responsibility of the ruling class to play their rule in this regard ${ }^{44}$. Such as, this thing was done in Shaykh Ahmad Sirhindi's era. This memorable effort done by Shaykh Ahmed Sirhindi has also been appreciated even by non Muslim Scholar. Hence, Professor S.H.A.R Gibbs writes:

Few top cholars have attempted to promulgate the Islamic Rule, after one another, during the $17^{\text {th }}$ and $18^{\text {th }}$ century. They not only emphasized on 'zahiri-shari'a and highlighted the psychological and behavior qualities. But this movement has not been given full attention. The main personalities of this movement are: Abd al- Ghani Nabulusi of Syria (1614to 1731), Ahmad Sirhindi of India (1564 to 1624) and Shah Wali Allah Delhvi (1702 to 1762). ${ }^{45}$

\section{Impact on Later Mughal Emperor}

The objectives of re-establishing the supremacy of Islam in sub-continent, initiated by Shaykh Ahmad Sirhindi was continued by his sons and other emperors. The Mughal king Shah Jahan (1627-1657) played a great role to save Islam in an age which was becoming secular. Shah Jahan, in keeping of his orthodoxy has been called by some historians, "faith defending Emperor" ${ }^{46}$ struggled to purify Islam and bring it in accord with the Shariat. Aurangzeb (1657-1707), under the influence of Sirhindi, issued in 1659 many ordinances 'to restore the rules of orthodox Islam in the administration and to bring the lives of the people according to teaching of the Quran .He abolished the persian festival Nauroz and music at court ${ }^{47}$. The teaching and practicing of other religion were stopped under the royal orders ${ }^{48}$. Jizya was re-imposed on the unbelievers in order to spread Islam and putdown the practice of infidelity ${ }^{49}$. Thus the tone of administration changed and the liberalism of the day of Akbar had stopped.

\section{Conclusion}

The literature supports that Shaykh Ahmad Sirhindi was not only a great scholar but also a social reformer leader. He played a vital role to establish the society based upon the teaching of Quran and Sunnah. He contributed significantly towards the protection of Muslim society from un-Islamic values and Hindu thought. A number of factors had weakened the religious and cultural consciousness of the Muslims. Numerous evils had been created by the people of Mughal court due to their attachment with the worldly gains. The Mughal emperor Akbar had introduced new religion called "Din-I-Ilaihi". The whole society was edge of darkness. It was a great achievement of Shaykh Ahmad Sirhindi to come back the Shariat in society. He wrote a large number of letters to Government personalities emphasizing the need of true teaching of Islam. He eradicated the evils of this class of society, and through letters strongly stressed upon those to follow the direction of the Holy Prophet. The teaching and preaching of Shaykh Ahmad

${ }^{44}$ Ibid.

${ }^{45}$ Gibb,Muhammedanism, 125 .

${ }^{46}$ Edwards, Mughal Rule in India,75.

${ }^{47}$ Ibid., 114

${ }^{48}$ Ellit and Dowson, The History of India as Told by His Own Historiana,vol.3. p.117.

${ }^{49}$ Edwards,Mughal Rule in India,117. 
Sirhindi fully showed its influence on the ministers and high ranking officers and indirectly Jahangir was also influenced. Moreover, Sirhindi teachings also had a great impact on later Mughal emperors. As a result, the whole society came under the flag of Islam through the efforts of Shaykh Ahmad Sirhindi.

\section{Biblography}

Abbot, Freeland (1962) "The Decline of the Mughal Empire and Shah Walliullah" The Muslim World, India.

Ahmad, Aziz. (1964) "Studies in Islamic Studies” Clarendon press, Oxford.

Ahmad, Aziz.(1964) "Muslim Culture in India" Clarendon Press, Oxford.

Ahmad, Jamil.(1971) “ Hundred Great Muslims”. Feroz Sons, Lahore.

Ahmad, Zubaida (1945) "The Contribution of India to Arabic Literature" Maktaba-yiDin wa Danish, Jullundur.

Ahmad, M.Masood.(2006) “Jahan-eImam-e-Rabbani” Imam Rabbani Foundation,. Karachi.

Algar, Hamid (1970) "The Naqshbandi Order: A Preliminary Survey of Its History and Significance". Studia Isla mica, India.

Ali, Anwar.(1979) “The Real Achievement of Human Life” Syed Publication, Karachi.

Allana, G. (1969) “Our Freedom Fighters” Paradise Subscription Agency, Karachi.

Azad, Muhammad Hussain.(1947) “Darbar-i- Akbari” Shaykh Mubarak, Lahore.

Baily, Gharam.(1938) "Studies in North Indian Languages” Lund, Humphries, Landon.

Baily John.(1989). "Professional Musicians of The City Heart" Cambridge University Press, Cambridge.

Badayuni,Abdul Qader.(1865). “Muntakhabut Tawarikh” Calcutta, India.

Burhan, Ahmad. (1940) "The Mujaddid's Conception Of Tawhid” Muhammad Ashraf, Lahore.

Chopra, Pran Nath.(1963) "Some Aspect of Society and Culture During the Mughal Age" Shiva Lal Wala, Jaipur.

Faruki, Zahirddin.(1997) “Aurangzib: His Life and Times” (2 ${ }^{\text {nd }}$ ed) Al Birni, Lahore. 
Faruqi, Abu-al-Hasan Zaid.(1982) "Hazrat Mujaddid and His Critics" Progressive Books, Lahore.

Friedmann, Yohanna.(1971) "Shaykh Ahmad Sirhindi: An Outline of His Thought and A study of Image in The Eyes of Posterity" Mcgill University Press, Montreal.

Garrett,H and Edwards, S.(1930) "Mughal Rule in India" Oxford University Press, Oxford.

Gibb,H.A.R.(1948) "Muhammadism: An Historical Survey". Oxford University Press, Oxford.

Hitti,P.K.(1957) “History of Syria” Macmillan, London.

Ibn Hassan.(1936) "Central Structure of Mughal Emperor" Oxford University Press, Oxford.

Ikram,Muhammad.(1940) “A Short History of Indo-Pak” Karachi.

Iqbal,Muhammad.(1989) “The Construction of Religious Thought in Islam” Iqbal Academy, Lahore.

Jehangir, Nur Jahan.(1960) “Tuzak-i-Jahangiri” Majlesa Tareqa Adab, Lahore.

Khan,Sarder Ali Ahmad.(1982) “The Naqshbandis” Darul Mubalegheen, Sharaqpur.

Malik,Hafiz.(1963) "Muslim Nationalism in India and Pakistan" Public Affairs Press, Washington,D.C.

Marshall,D.N.(1967) “Mughals in India” Mansell Publishing Ltd, London.

MMaclagan,Edward.(1995) "The Juesit and The Great Mughal" Manohar Pubisher, New Delhi.

Nizami,Khaliq Ahmad.(1965) "Naqashbandi Influnce on Mughal rulers and Politics" Islamic Culture Center, India.

Qurashi, Ishtiaq Ahmad.(1962) "The Muslim Community of The Indo-Pak Sub Continent" The Hague: Mouton and company.

Sirhindi,Shaykh Ahmad.(1877) “Maktobat Imam Rabbani” India.

Sharma,Ram.(1940) "The Religious Policy Of The Mughal Emperors" Asian Publishing House, London.

Vincent,A Smitm. (1958) “Akbar The Great Mughal” S Chand And Company, Delhi.

Yasin, Muhammad.(1974) “A Social History Of Islamic India” Munshiram Manoharlal, New Delhi. 